\title{
Ekologi Rumput Laut di Perairan Tanjung Pudak Kepulauan Karimunjawa, Jawa Tengah
}

\author{
Miftah Khudin*, Gunawan Widi Santosa, Ita Riniatsih \\ Departemen IImu Kelautan, Fakultas Perikanan dan IImu Kelautan, Universitas Diponegoro \\ JI. Prof. H. Soedarto S.H, Tembalang,Semarang, Jawa Tengah 50275 Indonesia \\ ${ }^{*}$ Corresponding author, e-mail: miftahkhudin91@gmail.com
}

\begin{abstract}
ABSTRAK : Penelitian mengenai struktur komunitas rumput laut ini dilakukan di Perairan Tanjung Pudak Pulau Karimunjawa. Penelitian ini bertujuan untuk mengetahui kondisi ekologi rumput dan struktur komunitas di Perairan Tanjung Pudak Pulau Karimunjawa. Pengumpulan data dilakukan bulan Mei 2016 pada lima stasiun menggunakan transek kuadran ukuran 50x50cm dengan interval antar stasiun 25 meter. Hasil penelitian menunjukkan bahwa selama penelitian ditemukan 7 spesies yang terbagi atas 2 divisi. Chlorophyta (3 spesies) dan Phaeophyta (4 spesies). Nilai keanekaragaman yang ditemukan berkisar antara rendah hingga sedang. Nilai keseragaman yang ditemukan berkisar sedang hingga tinggi, sedangkan nilai dominansi yang ditemukan berkisar rendah hingga sedang. Faktor yang mempengaruhi persebaran rumput laut adalah cahaya, suhu, salinitas dan jenis substrat. Kondisi komunitas rumput laut di perairan Tanjung Pudak, Pulau Karimunjawa masih tergolong baik, karena semua parameter kualitas air yang telah diukur memenuhi syarat bagi pertumbuhan optimum rumput laut kecuali kandungan nitrat dan fosfat.
\end{abstract}

Kata Kunci : Struktur Komunitas, Rumput Laut, Tanjung pudak

\section{Seaweed Ecology in the waters of Tanjung Pudak, Karimunjawa Islands, Central Java}

\begin{abstract}
This research was conducted in Tanjung Pudak waters, Karimunjawa Island, Central Java. The purpose of this research was to determine the ecological condition and community structure of seaweed in Tanjung Pudak waters. The data were collected on May 2016 in five stations, using the 50x50 cm-sized quadrant transect with 25 meters interval between each stations. The results showed that during the study found 7 species were divided into 2 divisions. Three species of Chlorophyta and four species of Phaeophyta. Diversity values were found in range from low to moderate. Uniformity values were found to be moderate to high, while dominance values were found in range from low to moderate. Factors that influence the distribution of seaweed are light, temperature, salinity and type of substrate. The condition of the seaweed community in the waters of Tanjung Pudak, Karimunjawa Island is still relatively good, because all measured water quality parameters qualify for optimum growth of seaweed except the content of nitrate and phosphate.
\end{abstract}

Keywords: Community Structure, Seaweed, Tanjung Pudak

\section{PENDAHULUAN}

Rumput laut merupakan tumbuhan thallus (Thallophyta) dimana organ-organ berupa akar, batang dan daunnya belum terdiferensiasi dengan jelas. Menurut Luning (1990), Indonesia memiliki tidak kurang dari 628 jenis rumput laut dari 8000 jenis rumput laut yang ditemukan di seluruh dunia.

Keberadaan rumput laut sebagai organisme produser memberikan sumbangan yang berarti bagi kehidupan binatang akuatik terutama organisme-organisme herbivora di perairan laut. Dari segi ekologi rumput laut juga berfungsi sebagai penyedia karbonat dan pengokoh substrat dasar yang bermanfaat bagi stabilitas dan kelanjutan keberadaan terumbu karang. Selain itu juga dapat menunjang kebutuhan hidup manusia sebagai bahan pangan dan industri (Suparmi, 2009).

Pulau Karimunjawa merupakan salah satu kepulauan yang memiliki keanekaragaman jenis rumput laut yang tersebar pada berbagai habitat dan belum teridentifikasi jenis dan sebarannya, baik pada ekosistem lamun maupun pada terumbu karang. Sedikitnya kajian khusus mengenai rumput laut di perairan Tanjung Pudak Pulau Karimunjawa yang menjadi alasan penelitian ini. 
Berdasarkan latar belakang tersebut, maka perlunya dilakukan penelitian untuk mengetahui penutupan, komposisi jenis, kepadatan dan sebaran rumput laut di perairan Tanjung Pudak, Pulau Karimunjawa.

\section{MATERI DAN METODE}

Pengambilan data sampel rumput laut dilakukan pada transek garis di setiap stasiun sampling dengan menggunakan metode transek kuadran ukuran $50 \times 50 \mathrm{~cm}$ sebanyak 5 buah transek kuadran di tiap transek garis. Penempatan transek kuadran pada transek garis dengan interval antar stasiun sampling berjarak setiap $10 \mathrm{~m}$ dengan jarak antar transek garis $25 \mathrm{~m}$. Pengambilan data dilakukan dengan metode sistematis sampling, dimana metode ini bertujuan untuk melihat kondisi sebaran dan penutupan rumput laut. Species rumput laut yang ditemukan dicatat selanjutnya dilakukan penghitungan jumlah koloni rumput laut di setiap luasan transek kuadran seluas $1 \times 1 \mathrm{~m}$ (pengulangan 4 kali luasan transek kuadran $50 \times 50 \mathrm{~cm}$ )

( Modifikasi dari English et.al, 1997).

Rumput laut yang ditemukan dalam penelitian ini adalah satu koloni dianggap satu individu. Jika satu koloni dari jenis yang sama dipisahkan oleh satu koloni lainnya maka tiap bagian yang terpisah itu dianggap sebagai satu individu tersendiri. Jika dua koloni atau lebih tumbuh di antara koloni yang lain, maka masing-masing koloni tetap dihitung sebagai koloni yang terpisah. Kondisi dasar dan kehadiran subsrat yang ditemukan di lokasi juga dicatat.

\section{Analisis Data}

Data kepadatan rumput laut diperoleh dengan menggunakan rumus Brower et al. (1990). Estimasi persen penutupan rumput laut digunakan estimasi yang dikembangkan oleh English et al. (1997). Menghitung komposisi jenis rumput laut digunakan rumus (Odum, 1971). Indeks keanekaragaman dan keseragaman dihitung dengan menggunakan rumus Shannon-Wiener (Krebs, 1983). Indeks dominansi dihitung dengan formula dari Simpson (Odum, 1993).
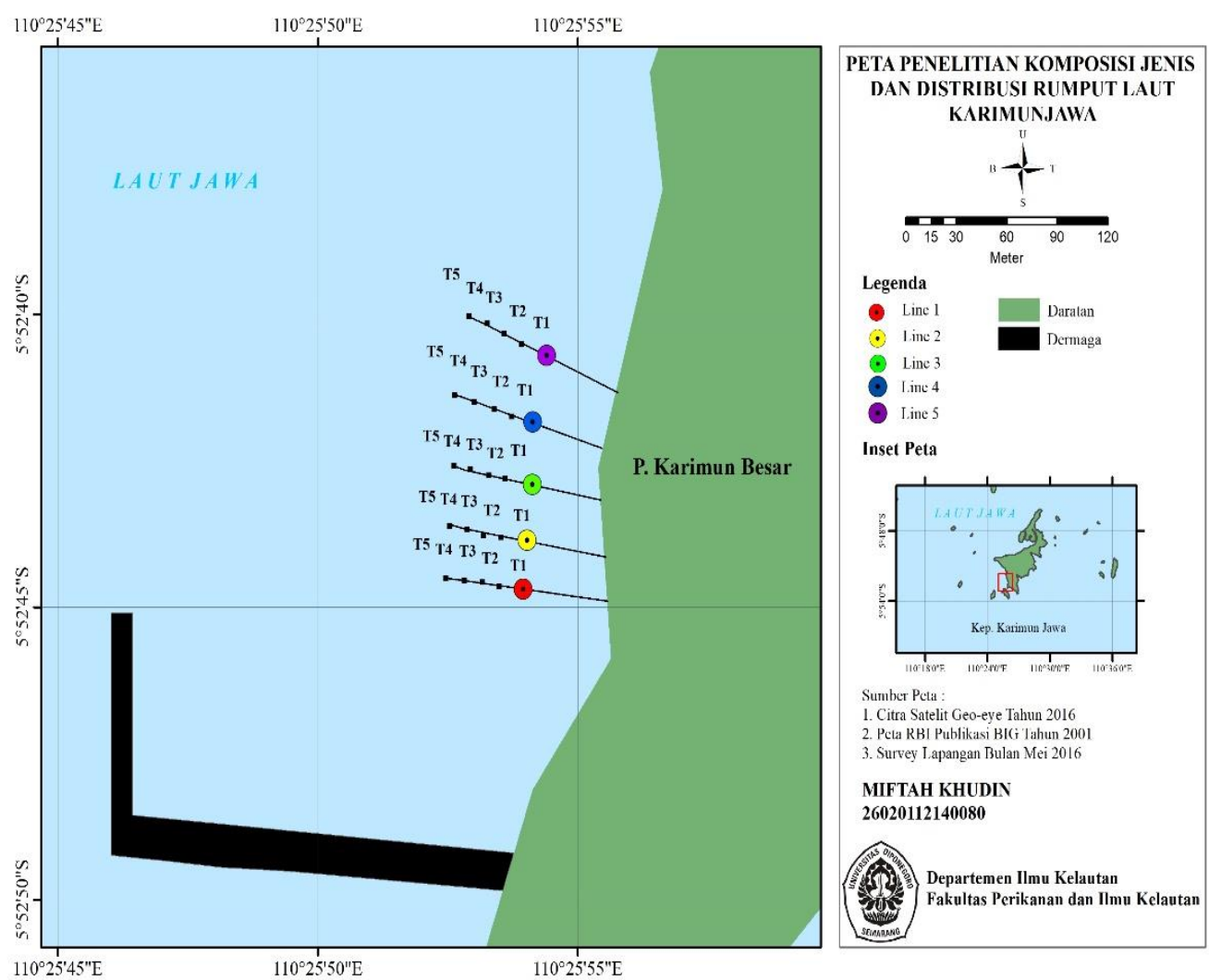

Gambar 1. Peta Lokasi Penelitian 


\section{HASIL DAN PEMBAHASAN}

Komposisi rumput laut yang ditemukan selama pengamatan di perairan Tanjung Pudak Pulau Karimunjawa disajikan dalam Tabel 1. Komposisi tersebut terdiri dari 7 spesies. Spesies rumput laut yang ditemukan termasuk dalam 2 divisi yang berbeda, yaitu Chlorophyta dan Phaeophyta. Hasil pengamatan pada jarak transek garis yang berbeda menghasilkan komposisi yang berbeda, hal ini disajikan pada Tabel 1. Padina australis dan Halimeda macroloba ditemukan pada setiap transek garis di preiran Tanjung Pudak Pulau Karimunjawa. Sargassum duplicatum hanya ditemukan pada transek garis ke kelima. Untuk rumput laut Turbinaria ornata hanya terdapat pada transek garis ke dua. Sedangkan rumput laut Dictyota spp. hanya ditemukan pada transek garis ke empat. Rumput laut Halimeda micronesica hampir ditemukan pada semua transek garis, hanya tidak ditemukan pada transek garis ke tiga. Rumput laut Caulerpa sp. ditemukan pada transek garis ke tiga dan ke lima.

Komposisi jenis rumput laut perairan Tanjung Pudak terdiri dari 7 spesies yang termasuk dalam 2 divisi, yaitu Chlorophyta (3 spesies), Phaeophyta (4 spesies) Tabel 4. Berdasarkan hasil pengamatan divisi Rhodophyta tidak ditemukan pada perairan tersebut, hal ini diduga karena pengaruh kedalaman dimana seluruh transek garis memiliki kedalaman berkisar $105-120 \mathrm{~cm}$. Menurut Nybakken (1992), rumput laut divisi Rhodophyta di perairan tropik umumnya terdapat di daerah bawah litoral dimana cahaya sangat kurang. Berdasarkan hasil pengamatan spesies yang paling banyak ditemukan adalah Padina australis dari divisi Phaeophyta dan Halimeda macroloba dari Divisi Chlorophyta. Hal ini diduga kondisi salinitas perairan pantai stabil yaitu antara $29-32 \%$. Menurut Luning (1990), salinitas yang ideal bagi pertumbuhan rumput laut antara 30-33 \% . Halimeda macroloba adalah salah satu jenis rumput laut yang bersifat stenohaline yaitu tidak tahan terhadap fluktuasi salinitas tinggi.

Komposisi jenis transek garis ke 3 lebih sedikit dibandingkan dengan transek garis yang lain. Hal ini diduga suhu pada transek garis lebih tinggi dibandingkan yang lain dengan kisaran suhu 33-35 ${ }^{\circ} \mathrm{C}$.

Karakteristik perairan pulau Karimunjawa memiliki substrat yang bervariasi yaitu pasir, karang mati dan batuan. Sesuai dengan penelitian Hartati et.al. (2017) dimana karakteristik perairan karimunjawa didominasi coarse sand dan fine sand. Spesies yang paling banyak ditemukan adalah Padina australis dari divisi Phaeophyta dan Halimeda macroloba dari Divisi Chlorophyta. Spesies-spesies diatas memiliki holdfast yang cocok untuk hidup dan tumbuh pada jenis substrat yang ada di perairan ini sehingga banyak ditemukan waktu pengamatan. Munurut Romimohtarto dan Juwana (2001) rumput laut tumbuh melekat pada lumpur, karang, pasir, batu dan benda keras lainya karena pada umumnya, tumbuhan ini bersifat litofotik atau melekat pada batu.

Tabel 1. Komposisi Rumput Laut yang ditemukan Pada Setiap Stasiun di Perairan Tanjung Pudak Pulau Karimunjawa

\begin{tabular}{|c|c|c|c|c|c|c|}
\hline \multirow{2}{*}{ No } & \multirow{2}{*}{ Jenis Rumput Laut } & \multicolumn{5}{|c|}{ Transek Garis } \\
\hline & & 1 & 2 & 3 & 4 & 5 \\
\hline \multicolumn{7}{|c|}{ Chlorophyta } \\
\hline 1 & Halimeda micronesica & + & + & - & + & + \\
\hline 2 & Halimeda macroloba & + & + & + & + & + \\
\hline 3 & Caulerpa sp. & - & - & + & - & + \\
\hline \multicolumn{7}{|c|}{ Phaeophyta } \\
\hline 1 & Padina australis & + & + & + & + & + \\
\hline 2 & Sargassum duplicatum & - & - & - & - & + \\
\hline 3 & Turbinaria ornata & - & + & - & - & - \\
\hline 4 & Dictyota spp. & - & - & - & + & - \\
\hline
\end{tabular}

Keterangan : (+) ditemukan , (-) tidak ditemukan 
Berdasarkan hasil pengamatan, terdapat perbedaan nilai kepadatan rumput laut pada setiap transek garis Tabel 5. Transek garis yang memiliki kapadatan rumput laut tertinggi ialah pada transek garis ke dua dan ke empat dengan jumlah 33 koloni rumput laut sedangkan kepadatan terendah ialah pada transek garis pertama dengan jumlah 28 koloni rumput laut. Spesies yang memiliki nilai kepadatan tertinggi adalah $P$. australis dengan rata-rata $18,4 \mathrm{koloni} / \mathrm{m}^{2}$, sedangkan spesies yang memiliki nilai kepadatan terendah adalah Sargassum duplicatum dengan rata-rata $0,2 \mathrm{koloni} / \mathrm{m}^{2}$.

Berdasarkan hasil yang telah didapat bahwa rumput laut jenis $P$. australis banyak ditemukan dengan rata-rata 18,4 koloni/m2. Rumput laut $P$. australis paling banyak ditemukan di perairan Tanjung Pudak, Pulau Karimunjawa. Hal ini diduga pengaruh dari nilai suhu di perairan ini yakni 30-34 ${ }^{\circ} \mathrm{C}$ dan salinitasnya yaitu 28-32 \% . Menurut Anggadiredja et al., (2009) pertumbuhan yang baik untuk rumput laut di daerah tropis adalah $20-30^{\circ} \mathrm{C}$. Menurut Kautsari et al., (2013) bahwa Padina toleran pada salinitas $27-32 \%$. Luning. (1990) menambahkan rumput laut umumnya hidup di laut dengan salinitas antara 30-33\%. Menurut Aslan (1998), hampir seluruh alga mempunyai adaptasi terhadap kisaran $\mathrm{pH}$ yaitu $6,8-9,6$. Jadi, nilai $\mathrm{pH}$ yang diamati yaitu antara 78, baik untuk pertumbuhan alga cokelat $P$. Australis. Menurut Kautsari et al., (2013), kisaran optimal pH untuk pertumbuhan Padina sp. antara 8,0 - 8,5.

Berdasarkan hasil pengamatan terlihat perbandingan yang cukup signifikan antara $P$. Australis dengan rumput laut yang lainnya. Hal ini diduga karena kandungan nitrat fosfat yang tinggi di Tanjung Pudak yaitu nilai nitrat berkisar antara 0,023-0,876 mg/L dan nilai fosfat berkisar antara 0,324-0,876 mg/L. Berdasarkan keputusan Kementrian Lingkungan Hidup (2004), standar baku mutu senyawa nitrat untuk biota laut adalah sebesar $0,008 \mathrm{mg} / \mathrm{L}$ dan fosfat untuk biota laut sebesar $0,015 \mathrm{mg} / \mathrm{L}$. Hal tersebut menunjukkan kadar nitrat dan fosfat di Tanjung Pudak telah melebihi ambang batas kesuburan suatu perairan, dimana nitrat dan fosfat pada konsentrasi tinggi dapat menghambat pertumbuhan rumput laut ( Atmadja et al, 1996).

Hasil penghitungan persentase penutupan menunjukkan bahwa terdapat perbedaan nilai persentase penutupan rumput laut pada setiap transek garis gambar 2 . Persentase penutupan rumput laut terluas terdapat pada transek garis ke empat dan ke lima $(26,56 \%)$ dan penutupan terendah pada transek garis pertama (18,75\%).

Kepadatan rumput laut berkaitan dengan persentase penutupannya, hasil pengamatan menunjukkan bahwa terdapat perbedaan nilai persentase penutupan rumput laut pada setiap transek garis. Nilai tertinggi persentase penutupan $26,56 \%$ yaitu pada transek garis 5 , sedangkan

Tabel 2. Kepadatan Rumput Laut (koloni/ $\mathrm{m}^{2}$ ) di Perairan Tanjung Pudak pulau Karimunjawa

\begin{tabular}{|c|c|c|c|c|c|c|c|}
\hline \multirow[b]{2}{*}{ No } & \multirow[b]{2}{*}{ Divisi Rumput Laut } & \multicolumn{5}{|c|}{ Transek Garis } & \multirow[b]{2}{*}{$\begin{array}{c}\text { Rata-rata } \\
\left(\text { koloni/ } \mathrm{m}^{2}\right)\end{array}$} \\
\hline & & 1 & 2 & 3 & 4 & 5 & \\
\hline \multicolumn{8}{|c|}{ Chlorophyta } \\
\hline 1 & Halimeda micronesica & 10 & 6 & 0 & 3 & 4 & 4,6 \\
\hline 2 & Halimeda macroloba & 12 & 9 & 3 & 4 & 2 & 6 \\
\hline 3 & Caulerpa sp. & 0 & 0 & 2 & 0 & 1 & 0,6 \\
\hline \multicolumn{8}{|c|}{ Phaeophyta } \\
\hline 1 & Padina australis & 6 & 16 & 25 & 23 & 22 & 18,4 \\
\hline 2 & Sargassum duplicatum & 0 & 0 & 0 & 0 & 1 & 0,2 \\
\hline 3 & Turbinaria ornata & 0 & 2 & 0 & 0 & 0 & 0,4 \\
\hline \multirow[t]{2}{*}{4} & Dictyota spp. & 0 & 0 & 0 & 3 & 0 & 0,6 \\
\hline & Jumlah & 28 & 33 & 30 & 33 & 30 & \\
\hline
\end{tabular}




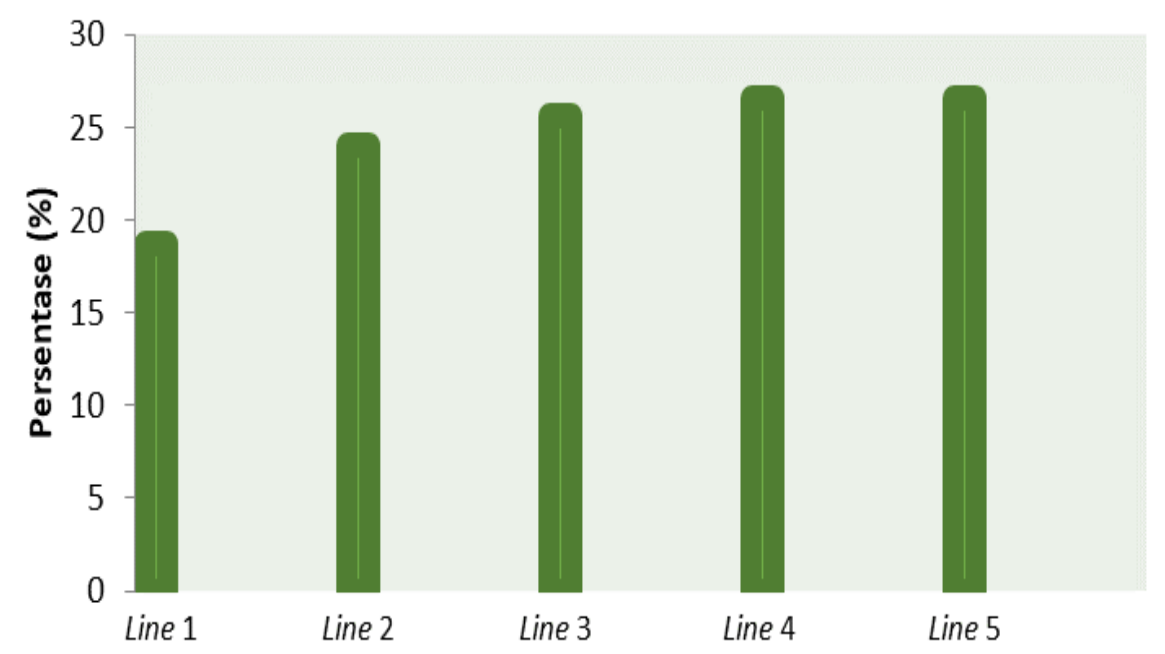

Gambar 2. Persentase Penutupan Rumput Laut di perairan Tanjung Pudak pulau Karimunjawa

nilai terendah persentase penutupan $18,75 \%$ yaitu pada transek garis 1 . Menurut Trono et al., (1988), keanekaragaman spesies lebih tinggi di perairan yang kondisi salinitasnya lebih stabil dibanding dengan perairan yang kondisi salinitasnya tidak stabil. Menurut Luning (1990), setiap alga laut memiliki toleransi terhadap kisaran salinitas tertentu untuk dapat hidup dan bertumbuhsecara maksimum. Pada transek garis 1 persentase penutupan rumput laut terendah diduga karena posisi transek garis 1 paling dekat dengan aktivitas dermaga Syah Bandar Pulau Karimunjawa, sehingga menyebabkan tidak stabilnya salinitas pada transek garis tersebut.

Nilai persentase tutupan terendah adalah pada transek garis 1. Diduga hal tersebut disebabkan pada transek garis 1 memiliki suhu yang paling rendah dibandingkan transek garis lainnya. Menurut Dawes (1981), suhu normal untuk pertumbuhan rumput laut adalah $25-35{ }^{\circ} \mathrm{C}$. Secara keseluruhan persentase tutupan tergolong rendah. Hal tersebut diduga kandungan nitrat fosfat yang tinggi di perairan Tanjung Pudak yaitu nilai nitrat berkisar antara 0,023-0,876 mg/L dan nilai fosfat berkisar antara $0,324-0,876 \mathrm{mg} / \mathrm{L}$. Kandungan nitrat dan fosfat pada konsentrasi tinggi dapat menghambat pertumbuhan rumput laut ( Atmadja et al, 1996).

Hasil pengamatan menunjukkan bahwa terdapat perbedaan dari komposisi jenis rumput laut di perairan Tanjung Pudak pulau Karimunjawa. Komposisi jenis tertinggi adalah Padina australis dengan nilai $59 \%$. Komposisi jenis terendah adalah Sargassum duplicatum dengan nilai 0,6\%.

Hasil indeks nilai penting tertinggi berdasarkan spesies yang ditemukan pada semua waktu yakni $P$. australis. Hal tersebut menunjukkan spesies ini memiliki peranan yang sangat tinggi dalam komunitas. Hal tersebut sesuai dengan pendapat Indriyanto (2006), semakin tinggi nilai penting suatu spesies maka peranannya di dalam komunitas semakin besar. Spesies ini memiliki indeks nilai penting tertinggi karena mempunyai nilai densitas relatif, frekuensi relatif dan penutupan relatif tertinggi juga. Selain itu diduga sebagian daerah intertidal perairan pantai ini memiliki substrat pasir berlumpur yang cocok sebagai habitat persebaran dari Padina australis. Hal tersebut sesuai dengan pendapat Nurmiyati (2013), yaitu spesies ini tersebar pada habitat pasir dan lumpur pada daerah pasang surut yang selalu tergenang oleh air.

Tabel 4 menunjukkan nilai keanekaragaman, keseragaman dan dominansi rumput laut di perairan Tanjung Pudak pulau Karimunjawa. Hasil pengamatan menunjukkan nilai keanekaragaman rumput laut sebesar 1,663, nilai keseragaman rumput laut sebesar 0,5925 dan nilai indeks dominansi rumput laut sebesar 0.418.Perairan pantai ini memiliki nilai indeks keanekaragaman yang sedang yakni 1,15. Menurut Odum (1993) nilai indeks keanekaragaman di kategorikan sedang apabila memiliki nilai $1,0<\mathrm{H}^{\prime}<3,0$. Hal ini diduga dipengaruhi oleh subtrat daerah tersebut adalah pasir. Menurut Atmadja et al. (1996), tempat yang memiliki substrat pecahan karang mati, batu, karang mati dan pasir yang stabil mempunyai keanekaragaman 
rumput laut yang lebih tinggi di bandingkan dengan tempat-tempat yang hanya bersubstrat pasir dan lumpur.

Nilai keseragaman yang sedang di lokasi penelitian, diduga faktor lingkungan, karena penyebaran rumput laut dipengaruhi oleh intensitas maupun panjang gelombang cahaya. Kedalaman di Tanjung pudak berkisar antara $105-120 \mathrm{~cm}$, sehingga kondisi perairan di pantai ini memiliki kecerahan $100 \%$ sehingga penetrasi bisa sampai ke dasar perairan.

Lunning (1990) menyatakan, keberadaan suatu jenis rumput laut pada kedalaman tertentu dipengaruhi oleh penetrasi cahaya matahari. Cahaya merupakan faktor dominan dalam menentukan distribusi vegetasi tumbuhan akuatik seperti rumput laut. Menurut Odum (1993), semakin kecil indeks keseragaman (E), maka semakin kecil pula keseragaman jenis dalam komunitas atau dengan kata lain penyebaran jumlah individu tidak sama dan ada kemungkinan didominasi oleh jenis tertentu.

Parameter lingkungan diukur untuk mendapatkan gambaran tentang kondisi oseanografi secara umum di setiap stasiun penelitian. Data parameter lingkungan dari setiap stasiun yang diambil disajikan pada Tabel 5. Tingginya kandungan nitrat dan fosfat di periran Tanjung Pudak, Pulau Karimunjawa yang ditunjukkan pada tabel 9 diduga akibat aktivitas kapal yang ada di pelabuhan Syah Bandar. Aktivitas kapal mengakibatkan terangkatnya kandungan nitrat dan fosfat yang berada didalam substrat perairan Tanjung Pudak. Tingginya nitrat dan fosfat juga diduga disebabkan masuknya limbah domestik yang ada disekitar perairan Tanjung Pudak. Menurut Belliveau dan Paul (2002), Sumber antropogenik fosfor adalah limbah industri dan domestik, yakni fosfor yang berasal dari detergen.

Tabel 3. Komposisi Jenis Rumput Laut di Perairan Tanjung Pudak pulau Karimunjawa, Jawa Tengah

\begin{tabular}{llc}
\hline No & \multicolumn{1}{c}{ Jenis Rumput Laut } & Komposisi Jenis (\%) \\
\hline Chlorophyta & \\
1 & Halimeda micronesica & 14.935 \\
2 & Halimeda macroloba & 19.480 \\
3 & Caulerpa sp. & 1.9480 \\
Phaeophyta & \\
1 & Padina australis & 59.740 \\
2 & Sargassum duplicatum & 0.6493 \\
3 & Turbinaria ornata & 1.2987 \\
4 & Dictyota spp. & 1.9480 \\
\hline
\end{tabular}

Tabel 4. Keanekaragaman ( $\left.\mathrm{H}^{\prime}\right)$, Keseragaman (E), dan Dominansi (C) Rumput Laut di perairan Tanjung Pudak pulau Karimunjawa, Jawa Tengah

\begin{tabular}{ccccccc}
\hline $\begin{array}{c}\text { Transek } \\
\text { Garis }\end{array}$ & $\mathrm{H}^{\prime}$ & Kategori & $\mathrm{E}$ & Kategori & $\mathrm{C}$ & Kategori \\
\hline 1 & 1,530 & sedang & 0,965 & tinggi & 0,357 & rendah \\
2 & 1,709 & sedang & 0,854 & tinggi & 0,346 & rendah \\
3 & 0,811 & rendah & 0,512 & sedang & 0,708 & sedang \\
4 & 1,361 & sedang & 0,680 & tinggi & 0,516 & sedang \\
5 & 1,303 & sedang & 0,561 & sedang & 0,562 & sedang \\
Total & 1,663 & sedang & 0,592 & sedang & 0,418 & rendah \\
\hline
\end{tabular}


Tabel 5. Kisaran Parameter lingkungan di perairan Tanjung Pudak pulau Karimunjawa selama penelitian

\begin{tabular}{cccccccc}
\hline No & Suhu $\left({ }^{\circ} \mathrm{C}\right)$ & $\begin{array}{c}\text { Salinitas } \\
(\%)\end{array}$ & $\mathrm{pH}$ & $\begin{array}{c}\text { Nitrat } \\
(\mathrm{mg} / \mathrm{L})\end{array}$ & $\begin{array}{c}\text { Fosfat } \\
(\mathrm{mg} / \mathrm{L})\end{array}$ & Kedalaman & Kecerahan \\
\hline Line 1 & $30-32$ & $30-32$ & $7-8$ & 0,324 & 0,786 & 115 & dasar \\
Line 2 & $31-32$ & $31-32$ & $7-8$ & 0,023 & 0,876 & 110 & dasar \\
Line 3 & $33-35$ & $30-31$ & $7-8$ & 0,768 & 0,324 & 105 & dasar \\
Line 4 & $32-34$ & $29-30$ & $7-8$ & 0,876 & 0,654 & 120 & dasar \\
Line 5 & $31-33$ & $29-30$ & $7-8$ & 0,456 & 0,765 & 110 & dasar \\
Baku & $27-32^{*}$ & $30-32$ & $7-8$ & $0,008^{* *}$ & $0,015^{\star *}$ & & \\
mutu & & & & & &
\end{tabular}

\section{KESIMPULAN}

Jumlah jenis rumput laut yang ditemukan di perairan Tanjung Pudak Karimunjawa terdiri dari 7 spesies. ( Halimeda micronesica, Halimeda macroloba dan Caulerpa sp., Padina australis, Sargassum duplicatum, Turbinaria ornata dan Dictyota spp.). Kepadatan rumput laut selama penilitian menunjukkan Padina australis memiliki kepadatan tertinggi (18,4 koloni/m2) dan Sargassum duplicatum memiliki kepadatan terendah $(0,2 \mathrm{koloni} / \mathrm{m} 2)$. Persentase tutupan tertinggi pada transek garis 4 dan 5 sebesar $26,56 \%$ dan terendah pada transek garis 1 sebesar $18,75 \%$. Komposisi jenis rumput laut tertinggi terdapat pada spesies $P$. australis dengan nilai rata-rata sebesar 59,74, nilai tersebut menunjukkan bahwa spesies ini memiliki peranan yang tinggi dalam komunitas. Komposisi jenis terendah pada spesies Sargassum duplicatum yakni sebesar 0.649, yang berarti perannannya dalam komunitas relatif kecil. Nilai keanekaragaman rumput laut di perairan Tanjung Pudak Karimunjawa berkisar antara rendah hingga sedang. Nilai keseragaman rumput laut di pantai ini berkisar antara sedang hingga tinggi. Sedangkan nilai dominansi yang terdapat di Pantai ini berkisar antara rendah hingga sedang.

\section{DAFTAR PUSTAKA}

Anggadiredja, J.T, Zatnika, A., Purwoto H. \& Istini. 2009. Rumput Laut. Penebar Swadaya. Jakarta. 147p.

Aslan,L.M. 1992, 1998. Budi Daya Rumput Laut. Kanissius. Yogyakarta.

Belliveau, S. A. \& Paul, V.J. 2002. Effects of herbivory and nutrients on the early colonization of crubtose coralline and fleshy rumput laute. Marina Ecology Progress Series. 232:105-114.

Brower, J.E., Zar, C.N., Jerold, H. \& Von Ende. 1990. Field and Laboratory Methods for General Ecology. 3ed edition. Wm. C. Brown. 237p.

Dawes, C.J., 1981. Marine Botany. John Wiley and Sons. University of South Florida. New York.

Hartati, R., Widianingsih, W., Trianto, A., Zainuri, M. \& Ambariyanto, A., 2017. The abundance of prospective natural food for sea cucumber Holothuria atra at Karimunjawa Island waters, Jepara, Indonesia. Biodiversitas Journal of Biological Diversity, 18(3):947-953.

Indriyanto. 2006. Ekologi Hutan. Bumi Aksara. Jakarta. 138-167 hlm.

Kautsari, N., Damar, A. \& Santoso, J. 2013. Potensi dan Karakteristik Natrium Alginat Padina australis Pada Kondisi Lingkungan Perairan yang Berbeda di Kabupaten Sumbawa. Bogor Agricultural University. Bogor.

Krebs, J.C., 1983. Ecology. The Experimental Analysis of Distribution and Abundance. Harper and Row Publisher. New York. 694 p.

Luning., 1990. Seaweeds, Their Environment, Biogeography And Ecophysiology. John Wiley and Sons. New York.

Nurmiyati, N., 2013. Keragaman, Distribusi Dan Nilai Penting Makro Alga Di Pantai Sepanjang Gunung Kidul. Bioedukasi, 6(1):12-21.

Nybakken, J.W., 1992. Biologi Laut Suatu Pendekatan Ekologis PT. Gramedia. Jakarta. 
Odum, E.P. 1971. Dasar-dasar Ekologi. Edisi ketiga. Gadjah Mada University Press. Yogyakarta. Hal 4-6.

Odum, E.P. 1993. Dasar-dasar Ekologi. Edisi ketiga. Penerjemah Tjahjono Saminga n. Gadjah Mada University Press. Yogyakarta. 697 p.

Romimohtarto, K. \& Juwana, S. 2001. Biologi Laut. Ilmu Pengetahuan Tentang Biota Laut. Penerbit Djambatan. Jakarta.

Trono, G.C., Ganzon., \& Fortes, F. 1988. Philippine Seaweeds. National Book Store Inc. Manila. Philippines. 